\title{
As Significações do Trabalho em A Hora da Estrela, de Clarice Lispector
}

\author{
The Meanings of the Concept 'labor' in \\ Clarice Lispector's Novel A Hora da Estrela
}

\author{
Angela Rubel Maria Fanini ${ }^{1}$ \\ Carla Silveira Lima Prado ${ }^{2}$
}

\section{RESUMO}

Este artigo analisa as representações do universo do trabalho em A Hora da Estrela, de Clarice Lispector. A abordagem se vale das reflexões de Karl Marx, Friedrich Engels, Georg Lukács e Ricardo Antunes. Resultou daí uma tipologia do trabalho em que este se constitui nas seguintes dimensões: mecanicista e alienante; humanizador e socializador; dicotômico entre trabalho material e intelectual e dado pela ótica do lucro e do status.

Palavras-chave: Literatura Brasileira. Romance. Universo do Trabalho e da Tecnologia.

\section{ABSTRACT}

This article analysis the literary representation of labor world in Clarice Lispector's $A$ Hora da Estrela. Some theoretical reflections on the world of work were used, taking the background of the theoretical discussion of Karl Marx, Friedrich Engels, Georg Lukács, and Ricardo Antunes. From these perspectives, work was represented as mechanic and alienating; medium of humanization and socializing; dichotomy between physical and intellectual work and from the perspective of profit and status.

Key-words: Brazilian Literature. Novel. Work and Technological Universe.

O foco deste artigo é o mapeamento e análise da representação literária do universo do trabalho na obra $A$ Hora da Estrela ${ }^{3}$, de Clarice Lispector, publicada em 1977, objetivando discutir e observar como a atividade laboral é concebida na formalização da vida, do sentido e do destino das personagens.

\footnotetext{
1 Profa. do Programa Intedisciplinar de pós-graduação em Tecnologia da UTFPR. Email: afanini@terra.com.br

${ }^{2}$ Graduanda do Curso de Letras da UTFPR e bolsista do CNPq de Iniciação Científica da UTFPR. Email: carlaprado2000@gmail.com

${ }^{3}$ LISPECTOR, C. A Hora da Estrela. 12 ed. Rio de Janeiro: Rocco, 1998. Doravante as citações dessa obra se referem a esta edição.
} 
Este estudo vincula-se à Linha de Pesquisa Tecnologia, Trabalho e Cultura, em um Programa Interdisciplinar, no qual se investiga como o texto literário representa o universo dos trabalhadores. Nos registros escritos, em diferentes épocas, culturas e grupos sociais, o ofício do trabalho tem sido concebido de maneiras distintas e isso contribui para formar, cristalizar e constituir identidades para o trabalho e trabalhador (a) nessas diferentes situações. No caso da Literatura Brasileira, a análise que considera a representação do universo do trabalho no âmbito ficcional é ainda escassa, visto haver poucas investigações com esse foco. A análise dessa representação discursiva é ainda bastante incipiente na área de Letras, justificando-se, assim, a pesquisa. O universo do trabalho tem recebido, sobretudo, a partir do século XIX, muitos estudos e interpretações. Karl Marx, Max Weber e Émile Durkeim despontam nesse período como grandes teóricos do trabalho. O texto literário, a partir de uma perspectiva materialista, articula-se à realidade e em assim sendo, também contribui para a construção de um certo olhar para a dimensão laboral.É sobre esse olhar, ou olhares, que objetivamos viabilizar esta proposta. O escritor é "homem de seu tempo e país" e, dependendo de sua visão de mundo, de sua atitude política e de seu comprometimento social, faz migrar para o interior do texto literário o trabalhador e a trabalhadora, narrando suas trajetórias, seus desejos, dramas e destinos. A Sociologia, a Economia, a História e a Filosofia tem se debruçado sobre essa dimensão e assim também ocorre com a Literatura Nacional. Estudá-la a partir desse foco é uma postura política que visa contribuir para uma discussão menos formalista e menos avessa ao contexto. Assim, pensa-se chegar a uma interpretação que alie Literatura e História real dos homens e mulheres que trabalham, disponibilizando-se uma análise contextualizada em que os docentes e discentes possam reconhecer na Literatura as pontes com a realidade.

Para alguns autores como Karl Marx (1986), Friedrich Engels (1990), Georg Lukács (1980) e Ricardo Antunes (2002, 2005), o ofício do trabalho é uma atividade vital e existencial para a constituição do ser social. Sem o trabalho, a subsistência, o desenvolvimento da sociedade e/ou do próprio homem, não seriam possíveis, ou

\footnotetext{
${ }^{4}$ Machado de Assis (1955), em Instinto de Nacionalidade, destaca que todo escritor não precisa deliberadamente converter sua obra em um documento da realidade, pois a articulação entre escritor, obra e realidade é um fato incontestável visto que o sujeito que escreve é historicamente situado e não foge ao seu contexto. Este lhe é interno, formalizando-se em sua linguagem literária. Assim também pensamos, entendendo que toda escritura remete ao contexto, pois daí vem e para a realidade se encaminha.
} 
seja, a atividade laboral é formadora; é elemento ontológico. A obra de Marx, majoritariamente, é destinada às interpretações das contradições entre capital e trabalho, destacando neste os reais sujeitos das mudanças políticas e econômicas para a construção de outro desenho social, demonstrando ser o trabalho coletivo (e significativo e não alienado e estranhado) a condição de emancipação dos sujeitos trabalhadores. Engels, parceiro intelectual de Marx, também defende a tese de que o trabalho é a condição básica de toda a vida humana. Para Engels (1990), todo o processo evolutivo humano - tanto físico como social - deveu-se ao trabalho. $\mathrm{O}$ homem somente deixa o reino da necessidade e sua condição de animal por intermédio do trabalho que modifica tanto o entorno natural quanto constitui o próprio homem, instituindo-o como ser social. Já para Lukács (1980), o trabalho é visto como elemento fundante do ser social e atividade imanente da própria existência humana, sendo elemento impulsionador para a dinâmica da vida em sociedade. O trabalho é a própria "práxis social" que dá sentido à vida em sociedade. A partir do trabalho causalidade e teleologia, subjetividade e liberdade, necessidade e emancipação se articulam, constituindo-se em uma ontologia do ser social. Antunes (2002, 2005), seguindo e atualizando essa linha de pensamento, enfatiza a necessidade de ter-se uma vida plena de sentido no trabalho. Essa plenitude do universo laboral se espraia para a vida fora do trabalho, imprimindo-lhe um novo sentido. Pensa-se em termos de totalidade em que a articulação positiva entre vida e trabalho traz satisfação ao ser humano, minimizando os problemas da falta de interação, como a fragmentação e a alienação. Esses autores advogam a centralidade do trabalho como condição de emancipação do sujeito e como elemento fundante do ser social. A sociabilidade está vinculada diretamente ao universo laboral. Na contemporaneidade, há já muitos autores, dentro do marco marxiano, que destacam a descentralidade do trabalho em virtude das mudanças econômicas, políticas e culturais. Neste estudo, não incorporamos essa discussão visto que a análise em tela nos propõe um embasamento teórico em que se enfatiza a centralidade.

Este estudo, portanto, propõe-se a perceber como ocorre a representação do trabalho no romance referido. A representação, no entanto, não está sendo vista como documento fiel dos fatores extraliterários, mas resultante da articulação recriadora do real operada a partir do universo literário. Pretende-se, então, em $A$ 
Hora da Estrela destacar e interpretar a representação do trabalhador nas diversas esferas funcionais e sociais, ressaltando-se a representação do escritor, da datilógrafa, da estenógrafa, do metalúrgico, das balconistas, do empresário, do médico e da cartomante.

Para isso, investiga-se nesta obra, como o escritor concebeu e formalizou, por intermédio da literatura, parte do contexto sócio-laboral de sua época. Segundo Cândido (1976), crítico literário e sociólogo, o aspecto da realidade que uma obra exprime (ou seja, os fatores extraliterários), não podem ser dissociados das operações formais postas em jogo, isto é, dos aspectos internos que garantem a autonomia da obra literária. É na dialética entre os componentes externos e os internos que se articula o discurso literário:

[...] só a podemos entender (a obra literária) fundindo texto e contexto numa interpretação dialeticamente íntegra, em que tanto o velho ponto de vista que explicava pelos fatores externos, quanto o outro, norteado pela convicção de que a estrutura é virtualmente independente, se combinam como momentos necessários do processo interpretativo. Sabemos, ainda, que o externo (no caso, o social) importa, não como causa, nem como significado, mas como elemento que desempenha um certo papel na constituição da estrutura, tornando-se portanto interno. (CANDIDO, 1976, p. 5-6)

Seguindo-se essa abordagem, pretende-se verificar como ocorrem as contradições e interações entre o externo e o interno, constituindo-se o texto literário não como espelho, mas em diálogo permanente com seu entorno. Também, seguese uma perspectiva materialista da linguagem em que se advoga que o signo lingüístico reflete e refrata ${ }^{5}$ a realidade. Há uma articulação entre as palavras e as coisas, porém mediada por muitas variáveis, a saber, a visão de mundo do autor e os discursos que constituem a fala do autor que estão conectados tanto a uma temporalidade imediata quanto a outra bem mais extensa que faz parte de um conjunto discursivo historicamente constituído e de longa duração.

\footnotetext{
${ }^{5}$ Reporta-se a Mikhail Bakhtin e V. N. Volochinov (1986), visto que é imprescindível se explicitar a concepção de linguagem subjacente a esta análise uma vez que o objeto de estudo se constitui de palavras que são a matéria-prima da Literatura. Esses autores estudam, entre outros temas, a linguagem a partir do corpus literário. Para eles, o signo lingüístico é campo de luta discursiva entre aquele que emite o discurso e aquele para quem o discurso é destinado. Aí ocorre uma verdadeira batalha ideológica de duplo sentido, constituindo os sujeitos sociais via linguagem. Esta porém, remete à realidade externa, sendo mediada pela luta de classes, pelo contexto e pela história real. Assim, tem-se uma posição materialista da linguagem. Esta reflete o real, vinculando-se ao contexto imediato, mas também o refrata haja vista que faz parte da linguagem uma temporalidade muito extensa, remontando-se há séculos. Além disso, a posição política dos sujeitos da linguagem também é fator de mediação do real, refratando-o.
} 
A fábula de $A$ Hora da Estrela, entre outras situações, narra parte da vida de Macabéa, retirante nordestina, na cidade do Rio de Janeiro. Macabéa tipifica o pobre, o solitário e o desprovido de certos atributos da cultura burguesa. Sua existência desliza entre o simplório e o complexo, causando estranhamento. Entre a mesmice de um dia e outro, conhece Olímpico de Jesus, jovem nordestino, pobre, audacioso e operário de uma metalúrgica. Este, porém, muito ambicioso, não vê em Macabéa atrativos físicos e possibilidade de ascensão social. Encontra esses elementos em Glória, colega de trabalho de Macabéa, carioca, oriunda de estratos médios da população, cujo pai era açougueiro, atributos que a tornam distinta na perspectiva de Olímpico. Sentindo constantes dores, Macabéa vai ao médico e descobre-se com tuberculose. Glória, compadecida da colega, aconselha-a a ir a uma cartomante. Madame Carlota profetiza felicidade e um grande amor na vida de Macabéa. Essa, ao sair da cartomante, é atropelada por um veículo luxuoso e morre.

Macabéa, oriunda do sertão do Alagoas, perde os pais quando criança, sendo criada pela tia, cursando o primário até o terceiro ano. Sabe cerzir e bater à máquina. No Rio de Janeiro emprega-se em uma firma de representação de roldanas. Apesar de ganhar menos de um salário mínimo, orgulhava-se de sua profissão de datilógrafa. Na época da fábula, década de setenta do século $X X$, a datilografia era um dos requisitos principais para a inserção no mundo de trabalho em escritórios e os cursos de datilografia eram disputados pelos aspirantes a uma vaga de emprego, dada a importância dessa função.

No entanto, embora o exercício da datilografia implique mecanização, o trabalho de Macabéa não é mecânico, mas suscita, em parte, interferência, bemestar e modificação. Embora a máquina de escrever no ambiente de trabalho imponha seu uso ${ }^{6}$, Macabéa resiste à padronização da escrita, pois reflete sobre as contradições entre linguagem escrita e falada. Apesar da ausência de educação formal média, Macabéa questiona o sistema ortográfico vigente da Língua Portuguesa. Resiste em escrever duas consoantes juntas, pois se angustia pelo fato de que não há homologia entre fala e escrita. Essa resistência demonstra que a

\footnotetext{
${ }^{6}$ Dialoga-se com Francisco Rüdiger (2006), que enfatiza a posição de Martin Heidegger sobre a questão da colonização do pensamento e da linguagem por intermédio da imposição do maquinismo e da máquina sobre o trabalho cotidiano. Nessa obra, destaca-se a imposição de certa uniformização e padronização da escrita tanto da máquina de escrever e a posteriori do computador, na editoria de textos. A máquina, imperando sobre o corpo, ou seja, sobre, neste caso, a mão do escrevente, impõe um certo ritmo e padrão de trabalho que coloniza também o pensamento que se torna maquinístico.
} 
personagem tenta exercer forças centrífugas em relação às forças centrípetas dominantes na ortografia escrita padrão culta. A personagem, aparentemente simplória e passiva, mesmo se utilizando de uma máquina de escrever, que exerce um papel de padronização na escrita, emerge como sujeito de volição a partir de seu questionamento, propiciado pelo exercício do trabalho cotidiano com as palavras. Recusa-se a apenas copiar e datilografar, demonstrando desejo de mudar e intervir:

\footnotetext{
Por ser ignorante era obrigada na datilografia a copiar lentamente letra por letra - a tia é que lhe dera um curso ralo de como bater à máquina. $\mathrm{E}$ a moça ganhara uma dignidade: era enfim datilógrafa. Embora, ao que parece, não aprovasse na linguagem duas consoantes juntas e copiava a letra linda e redonda do amado chefe a palavra "designar" de modo como em língua falada diria: "desiguinar". (LISPECTOR, 1998, p.15)
}

O trabalho de datilografar textos propicia uma certa reflexão sobre os termos que escreve, despertando a curiosidade pelas palavras, letras e pelos termos desconhecidos. Apaixona-se por termos difíceis da Língua Portuguesa sobre os quais divaga. Um dos prazeres da nordestina é recortar e colecionar anúncios dos jornais velhos do escritório em que trabalha, lendo-os à noite, à luz de velas. $\mathrm{O}$ mundo fora do trabalho é também impactado e ressignificado pela atividade laboral. Entretanto, embora essa atividade Ihe propicie certa subjetivação e problematização, não é socializada com os demais colegas de repartição. Macabéa permanece bastante solitária em meio a um entorno, em certa medida, impassível às suas necessidades e descobertas.

Embora o ambiente da firma de roldanas em que trabalha e os relacionamentos que aí estabelece, funcionem como elo social e de comunicação com o mundo, não se trata de uma vida plena de sentido no trabalho. O narrador refere-se à protagonista como um "parafuso dispensável": "[...] Nem se dava conta de que vivia em uma sociedade técnica onde ela era um parafuso dispensável." (LISPECTOR, 1998, p.29). Macabéa apresenta-se distópica, ou seja, não se enquadra na competência profissional mecanicista que lhe é imposta, cometendo desvios da norma ao datilografar de modo "errado" e se comunica pouco em seu ambiente de trabalho. A sua origem humilde e atitude passiva à hierarquia contribuem para o isolamento. Outrossim, essa situação alienante não é absoluta, uma vez que a personagem vê um sentido no trabalho que se estende também para a vida pessoal. 
Quanto ao ofício da costura, não o exerceu mais depois que deixou sua terra natal. Porém, lembra desse oficio quando passeia pela Zona Sul da cidade e permanece a olhar as vitrines de roupas "acetinadas". O produto da vitrine não lhe é de todo estranho e alheio. Apreende vínculos entre o seu trabalho anterior e o que vê. Trabalho, trabalhador e produto entram em certa sintonia, nem que essa seja amena e ocorra em âmbito apenas individual. Na ótica do narrador, talvez a restauração dessa profissão proporcionasse mais dignidade e sentido à vida da personagem: "Aprendera em pequena a cerzir. Ela se realizaria muito mais se se desse ao delicado labor de restaurar fios, quem sabe se de seda. Ou de luxo: cetim bem brilhoso, um beijo de almas. Cerzideirinha mosquito." (LISPECTOR, 1998, p.26).

Vê-se, portanto, que há uma ponte entre trabalho e vida cotidiana para Macabéa. Esse trânsito entre uma esfera e outra, entre o labor coletivo e a vida privada, é elemento constituinte e formador da personagem, imprimindo-lhe certa complexidade.

Tendo por base os teóricos referidos, Macabéa não se enquadra no sujeito trabalhador marxiano, pois não exerce sua profissão nas grandes fábricas urbanas e sim em um pequeno escritório. Nesse cenário de poucos empregados e de tratamento diferenciado para cada um em que a personagem é hierarquicamente inferior a todos, a possibilidade de plena conscientização e de pertencimento a uma classe de trabalhadores explorados se enfraquece. Entretanto, pode-se usar a categoria referida por Antunes (2002), enquadrando-a na classe-que-vive-do trabalho ${ }^{7}$, pois somente a partir do trabalho é que sustenta sua vida material e social, sendo a atividade laboral uma categoria central para ela. O meio laboral, embora ausente de condições que Ihe possibilitem se emancipar plenamente, visto seu caráter desassociado, é um dos únicos cenários a partir do qual interage socialmente. A empresa em que trabalha, por seu caráter de micro empresa, permite, no entanto, uma relação de certa intimidade com os colegas e com o

\footnotetext{
${ }^{7} \mathrm{~A}$ obra marxiana, majoritariamente, endereça-se para o operariado urbano e fabril, depositando nesse sujeito suas esperanças de que altere a realidade a partir de uma tomada do poder mediante a Ditadura do Proletariado, apossando-se dos meios de produção e abolindo a propriedade privada. Ricardo Antunes (2002), ao escrever no século XX, destaca a necessidade de se ampliar o sujeito dessa intervenção social, preferindo usar o termo classe-que-vive-do-trabalho, agregando aí os vários setores da economia. Isso decorre, sobretudo, da diminuição do operariado fabril em virtude dos processos de automação e da ampliação do setor de serviços. Assim, pode-se vincular a personagem Macabéa a essa nova realidade do mundo do trabalho.
} 
patrão. Essa proximidade a faz se sentir parcialmente membro dessa comunidade e em certa medida constitui uma nova identidade para ela. Passa a ser uma trabalhadora, do trabalho imaterial, em meio urbano, na cidade grande e se relacionando com pessoas oriundas da classe média carioca. Distante está de sua identidade anterior, rural, de cidade menor, sem emprego, relacionando-se apenas com a tia. O trabalho, portanto, Ihe confere certa emancipação, altera sua identidade e Ihe dá a possibilidade de subjetivação, sobretudo, esta vinculada ao trabalho imaterial com as palavras e sua problematização. Remete-se aí também a Lukács (1980) quando este destaca que a subjetividade decorre do trabalho, constituindo-se pelas escolhas e opções do sujeito. Macabéa tem opções limitadas, mas não deixa de expressá-las, mormente, no tocante à inversão da ortografia. O trabalho, além de Ihe possibilitar certa mobilidade social e pessoal, é também instrumento para o consumo. A personagem já se acha influenciada pela indústria cultural, consumindo seus produtos à medida que vai ao cinema ver Mariliyn Moroe e toma coca-cola. $\mathrm{O}$ trabalho também apresenta um caráter instrumental, reduzindo-se a instrumento para o consumo, reforçando o que enfatiza Bauman (2008), na ascensão do consumidor e no enfraquecimento do cidadão. Macabéa, com certeza, não encarna o trabalhador emancipado e politizado, desejando a alteração social, mas dentro de seus limites contextuais, tem no trabalho a condição mínima de sentido para sua existência como destaca Antunes (2002, 2005).

Olímpico de Jesus, namorado de Macabéa, é paraibano e foi criado pelo padrasto. Caracterizado como astuto e de caráter vil, almeja ser rico e famoso. Trabalha como operário em uma metalúrgica. Olímpico, assim como Macabéa, representa o nordestino pobre que se dirige à cidade grande no anseio de alcançar uma vida melhor. O contexto extraliteráio representado na obra atrela-se ao período histórico de forte industrialização das montadoras de automóveis. O trabalho da personagem é braçal: "O trabalho consistia em pegar barras de metal que vinham deslizando de cima da máquina para colocá-las embaixo, sobre uma placa deslizante. Nunca se perguntara por que colocava a barra embaixo" (LISPECTOR, 1998, p.45).

Seu trabalho exige qualificação média e sua função é mecânica, trabalhando maquinalmente, sem se questionar explicitamente a esse respeito. Encontra-se 
dentro do sistema fordista-taylorista de $\operatorname{produção~}^{8}$, que contribui para a alienação do operário, visto que este executa a atividade com pouquíssima margem de ingerência, negociação e subjetivação. O personagem não é formalizado enquanto operário sindicalizado e politizado, refletindo parte do contexto social do movimento sindical brasileiro da década de setenta. A Autora optou por formalizar uma personagem que se desvia do padrão de parte do operariado metalúrgico daquele momento para quem o ambiente do trabalho é o campo possível de luta contra a desmedida do capital. Ao personagem não interessa lutar contra o sistema visto que almeja mudar de classe social e não permanecer como operário. A trajetória do personagem é urdida de tal forma que já demonstra o seu anseio por alterar a sua condição social no intuito de se apossar do poder em benefício próprio. Interessa-se por discursos, política e quer ser deputado pelo Estado da Paraíba. A Autora parece alocar nesse personagem as diferenças entre o âmbito do trabalho e o âmbito da política e esta na sua forma privatizada. A não subjetivação do trabalho por parte de Olímpico decorre tanto de sua trajetória pessoal quanto por estar assujeitado à linha de produção mecanicista que dificulta sobremaneira qualquer ingerência. O mundo do trabalho material e mecânico não propicia uma reflexão explícita, mas, com certeza, leva a uma atitude de rejeição em sua totalidade, fazendo com que o personagem deseje dele se afastar, abrindo-se para outras oportunidades. $O$ trabalho mecanicista não coloniza a sua mente, mas também não o instiga a se contrapor, afastando-o de uma possível politização. O trabalho não confere sentido à sua existência, não é socializante e não é central em sua vida. É uma etapa da qual se utiliza para sobreviver, mas que rejeita. O personagem é descrito como alguém pensante e que medita em mudanças, embora nunca tenha usado dessas competências para se associar aos outros operários, liderando movimentos de mudança. Não personifica, portanto, o operariado associado em luta em prol de melhorias trabalhistas.

Os negócios públicos interessavam Olímpico. Ele adorava ouvir discursos. Que tinha seus pensamentos, isso lá tinha. Acocorava-se com o cigarro barato nas mãos e pensava. Como na Paraíba ele se acocorava no chão, o traseiro sentado no zero, meditar. Ele dizia alto e sozinho: - Sou muito

\footnotetext{
${ }^{8}$ Antunes (2002, 2005), seguindo estudos clássicos sobre trabalho, entende fordismo-taylorismo como a forma pela qual a indústria e o processo de trabalho daí decorrente consolidam-se ao longo do século $\mathrm{XX}$, cujos elementos constitutivos básicos são dados pela produção em massa, através da linha de montagem e de produtos mais homogêneos. O trabalhador é praticamente desprovido de volição e interferência na gestão da produção, ocorrendo sua parcial reificação.
} 
inteligente, ainda vou ser deputado. E não é que ele dava para fazer discursos? Tinha o tom cantado e o palavreado seboso, próprio para quem abre a boca e fala pedindo e ordenando os direitos do homem. (LISPECTOR, 1998, p.46)

A política, no entanto, não é pensada como atividade de representação do bem comum, de uma vontade coletiva. O trabalho político é visto por Olímpico como uma ponte para atingir os próprios intentos; acredita que com esta função terá status, riqueza e poder e deixará a vida medíocre que leva. Em sua concepção da política predomina o espaço privado, o eikos ${ }^{9}$, e não o público, a ágora. $O$ trabalho aqui é representado e vislumbrado como uma ação individualista, perdendo seu potencial emancipatório enquanto elemento de mudança coletiva.

Por conta de suas aspirações, Olímpico rompe o namoro com Macabéa, que não lhe pode oferecer ascensão social. Começa a namorar Glória, haja vista esta fazer parte da média burguesia, ser melhor remunerada e carioca "da gema" e ter nascido no Rio de Janeiro, que para Olímpico era um ponto positivo, pois significava melhoria de status social.

A personagem Glória, carioca e de uma família de classe média, é colega de trabalho de Macabéa na firma de roldanas. Exerce o ofício de estenógrafa, que consiste em um método abreviado ou simbólico de escrita que tem por objetivo maximizar a velocidade do ato de escrever e registrar simultaneamente o que está sendo falado. A atividade exige agilidade e mecanização. Por conta de sua função e origem social, o salário de Glória é maior. Não apresenta dificuldade com as palavras, conforme o texto nos informa e também não problematizava sua profissão, exercendo-a maquinalmente, sem refletir nas palavras e nos seus significados. $O$ trabalho é aceito e realizado não propiciando a reflexão. E, assim Glória também não apresenta atitude reflexiva e questionadora na vida fora do trabalho. Trabalho e vida se interconectam, mas no sentido do vazio e do mecânico. O trabalho só reforça a posição social e pessoal da personagem, não levando a nenhuma mudança, indo de encontro à idéia de que a atividade laboral pode levar a algum grau de conscientização política no sentido de agir e modificar o entorno. A empresa em que trabalha mais parece uma extensão do ambiente da família, gerando

\footnotetext{
${ }^{9}$ Toma-se a discussão de Zygman Bauman (2008), sobre a ascensão da sociedade individualizada em que $o$ indivíduo somente entra na ágora para se beneficiar individualmente. $O$ crescente individualismo e o enfraquecimento do coletivo é visto como nefasto, sendo uma força constituinte da sociedade globalizada sob a égide do capital e do consumo. A privatização do coletivo, historicamente construída no Brasil, é dada por autores já clássicos como Gilberto Freyre, Sérgio Buarque de Buarque, Caio Prado Júnior e Roberto DaMatta.
} 
intimidade, comprometimento e estabilidade. Esvazia-se o conflito visto que o ambiente se assemelha a um cenário familiar em decorrência de certa homogeneidade social, econômica e cultural de seus membros.

O personagem Raimundo Silveira encarna o papel do burguês, medianamente culto e proprietário da firma de representação de roldanas. Chefe de Macabéa e de Glória tem afinidade pela leitura e gosta de palavras difíceis. Macabéa seduz-se pelas palavras, demonstrando certa sintonia com Raimundo, revelando-se que as relações de trabalho constroem mediações, contradições e desejos interpessoais. O ambiente de trabalho na firma de roldanas tem um papel socializador, haja vista que as relações de trabalho entre Macabéa, o chefe e Glória são de certa forma positivas, pois Glória se apieda da condição miserável de Macabéa, indicando-lhe a cartomante e o médico e o chefe pensa em demiti-la, mas não o faz, demonstrando haver certos laços de solidariedade laboral e pessoal. O universo laboral constrói uma certa ação comunicativa e coletiva, integrando, de certo modo, seus membros. Trabalho e sociabilidade se interpenetram. Atitudes maternais de Glória e paternais de Raimundo emergem na empresa, reforçando a pessoalidade das relações, longe de um contexto impessoal de grandes empresas. Macabéa não permanece na empresa por mérito técnico, mas por piedade, confirmando uma articulação entre trabalho e sociabilidade, reforçando-se as teses em prol da centralidade do trabalho na constituição do ser social.

O personagem narrador do romance, Rodrigo S.M. trata do ofício de escrever e da tentativa de dar vida à sua personagem e à sua narrativa. Rodrigo dialoga com o leitor sobre o estilo da própria narrativa; considera-se mal sucedido e ironiza os próprios textos. Julga não se enquadrar em nenhum parâmetro social, refletindo como a sociedade o vê: "A classe alta me tem como um monstro esquisito, a média com desconfiança de que eu possa desequilibrá-la e a classe baixa nunca vem a mim." (LISPECTOR, 1998, p.19). Aqui, tem-se a visão de que o intelectual está fora da estratificação social. Essa perspectiva é bastante complexa e coloca o intelectual como "flutuante", terminologia de Mannhein ${ }^{10}$. A linguagem literária é apresentada ora incomunicável, ora tendo poder de desestabilizar. A posição do intelectual

\footnotetext{
${ }^{10}$ Para Karl Mannhein (1986), o intelectual, embora advenha de uma classe social, dela se desvincula parcialmente, ao exercer o papel de intelectual. Ele se aloja em uma camada "intersticial" da sociedade visto que seu pensamento de síntese se atrela a saberes mais amplos que o específico de classe. Contém a classe, mas não exclusivamente, levando-o a ter de si uma visão de imparcialidade e de distopia social.
} 
trabalhador é questionada a partir de dois mirantes, o da classe alta e o da média, segundo o próprio narrador. Isso coloca o seu trabalho em confronto com a comunidade, apontando para a sua distopia. Entretanto, na obra em tela, é mais precisamente sobre a classe "incomunicável" que o escritor se debruça. O discurso romanesco se volta para o pequeno, o humilde, no anseio de se comunicar. Seguindo Bakhtin (1988), tem-se que o romance se volta, diferentemente da epopéia, para o não heróico: "Não só o riso, mas as lágrimas, o que é pequeno, o sentimental em vez do grande, do altivo, do eloqüente: o outro que não tem autoridade. O animal, a criança, a mulher fraca, o imbecil e o idiota, a florzinha, tudo quanto é pequeno, e assim por diante." (BAKTHIN, p.379). Macabea é essa voz impotente, assemelhando-se à do escritor.

O trabalho imaterial do escritor, a partir do narrador, é uma tentativa de gerar a personagem Macabéa e acaba se transformando em um martírio para o narrador visto que, segundo ele, é necessário desnudar-se do seu universo intelectual, de sua erudição e de suas benesses de classe para penetrar no ambiente "oco" da personagem Macabéa:

[...] para falar da moça tenho que não fazer a barba durante dias e adquirir olheiras escuras por dormir pouco, só cochilar de pura exaustão, sou um trabalhador manual. Além de vestir-me com roupa velha rasgada. Tudo isso para me pôr no nível da nordestina. (LISPECTOR, 1998, p.19)

Aqui se apresenta a dicotomia entre o trabalho imaterial e o trabalho material. O narrador não consegue uni-los facilmente e destaca a antinomia entre ambos. Personagem e narrador estão em pólos sociais díspares e em campos laborais opostos. A problemática da estratificação social e cultural é evidente no texto. Rodrigo e Macabéa não fazem parte do mesmo contexto sócio-econômico. Ele exerce o trabalho imaterial e intelectual, vive do exercício da palavra e tenta narrar e apreender o externo, o extraliterário que lhe é estranho, alheio e resiste às palavras. Macabéa representa os sujeitos extraliterários que, embora constituídos, a partir das mediações do escritor, por essa palavra erudita, dificilmente terão acesso a essa construção. O trabalho imaterial parece incapaz de construir pontes de comunicação entre classes diferentes. O escritor cria a personagem a partir de certa realidade limitada a seu campo de visão. Essa criação do externo, no entanto, é inócua ao objeto recriado visto ser incomunicável a ele. Entre as palavras e as coisas há mais cisão que união. Daí reside o conflitante choque de visões de mundo de duas 
classes sociais antagônicas, com concepções de mundo distintas. O trabalho imaterial não agrega facilmente os sujeitos sociais. Vê-se que o autor embora tenha um excedente de visão ${ }^{11}$ sobre a personagem, essa lhe escapa, não se deixando facilmente objetificar. Macabéa é dada como simplória, "oca”, mas em dadas situações, já mencionadas, emerge como sujeito complexo que por intermédio inclusive das palavras, toma consciência de si, mesmo que de modo tênue. Essa situação é destacada quando a personagem é seduzida pelo título da obra Ofendidos e humilhados de Fiodor Dostoiesvski que jaz sobre a mesa do chefe. Por um instante, a sua condição humilde e de pertencimento de classe se revelam para ela e a personagem mais uma vez escapa à sua simplicidade e inconsciência. Autor e personagem não coincidem. A situação entre ambos é tensa e conflituosa. $O$ externo contraditório e irredutível migra para o interior do texto, constituindo-se composicionalmente, uma vez que a própria linguagem do narrador sobre Macabéa não está isenta de contradições.

Embora haja complexas problematizações sobre o trabalho imaterial, vê-se que é a partir deste que o sujeito escritor exerce a liberdade de recriar o externo, subjetivando-o. Essa subjetivação, no entanto, faz-se a partir da presença do outro, ou seja, ocorre no intersubjetivo. A "liberdade e subjetivação" do dado externo, como assevera Lukács, também obedece a uma "teleologia" que move o sujeito no processo do trabalho criativo desde o início. O objetivo do escritor, colado ao narrador, é apresentar esse universo de Macabéa por intermédio de sua lida com as palavras e é nesse trabalho árduo que nos oferece uma imagem possível da personagem.

Por causa das constantes dores no corpo, Macabéa é aconselhada pela colega Glória a procurar um médico. Temos, então, a representação do profissional da saúde, que exerce a profissão sob a ótica do lucro e do status. O trabalho aí não socializa, não beneficia e nem dignifica quem o exerce. A estratificação social define a prática laboral que ocorre de modo reduzido e simplificado. A competência e a eficiência da atividade médica não são necessárias uma vez que são destinadas aos

\footnotetext{
${ }^{11}$ Toma-se a discussão de Bakhtin (1988), sobre as relações entre autor e personagem em que aquele, embora tenha uma perspectiva exotópica em relação à personagem, esta, em certos romances, não se submete à total objetificação, entrando em confronto com o autor.Essa discussão sobre a complexa relação entre criador e criatura nos leva a repensar a questão de saber e poder. A partir dessa reflexão bakthiniana, vê-se que a reificação, a taxinomia, a denominação e a classificação do outro não é simples e não ocorrre sem conflito e percalços.
} 
indivíduos desvalidos economicamente. A mediação de classe social esvazia a profissão:

Esse médico não tinha objetivo algum. A medicina era apenas para ganhar
dinheiro e nunca por amor à profissão nem aos doentes. Era desatento e
achava a pobreza uma coisa feia. Trabalhava para os pobres detestando
lidar com eles. Eles eram para ele o rebotalho de uma sociedade muito alta
à qual também ele não pertencia. Sabia que estava desatualizado na
medicina e nas novidades clínicas, mas para pobre servia. O seu sonho era
ter dinheiro para fazer exatamente o que queria: nada. (LISPECTOR, 1998,
p. 67-68)

Há na narrativa, sinteticamente abordado, o ofício das colegas de quarto de Macabéa: Maria da Penha, Maria Aparecida, Maria José e Maria apenas. São balconistas das Lojas Americanas. Balconista ou atendente é uma das profissões mais tradicionais do varejo e também uma função em que o desemprego é mais raro, visto que não exige qualificação mais complexa como, por exemplo, no setor industrial. Representando o setor de serviços, as "Marias" desempenham um trabalho anônimo, genérico e que exige pouca experiência e habilitação. O próprio nome das personagens e a narrativa breve e sintética sobre elas já denota sua substituição por qualquer outro (a). As colegas de quarto de Macabéa representam uma grande parcela dos trabalhadores, distribuída no varejo brasileiro, desempenhando uma função pouco satisfatória do ponto de vista de criar dignidade, subjetividade e decência para o trabalhador. Embora o trabalho aí seja estranhado no sentido marxiano, é o único cenário que dá vida às personagens. Entretanto essa vida parece esvaziada de sentido.

Por fim, temos a figura da cartomante Madame Carlota, que atende os clientes em um apartamento térreo na esquina de um beco. Macabéa vai consultá-la por indicação da colega Glória, que segue fielmente os conselhos da sortista. De gênio forte e má índole, Mme Carlota vale-se desse ofício para extorquir as pessoas e atingir seus intentos mercantis. A mancia (adivinhação do futuro) é uma atividade muito antiga e tem suas raízes nas civilizações orientais. $\mathrm{Na}$ antiga Grécia, o exercício da arte divinatória era atividade exercida pelos oráculos, que faziam as predições por meio de conexões com os deuses. O discurso, constituído entre o sagrado e o secular, previa o desenrolar tanto de eventos coletivos quanto pessoais do povo heleno. Baseados nas previsões do oráculo, o povo e seus líderes traçavam suas estratégias de domínio e sobrevivência.

As artes adivinhatórias, na sociedade secular ocidentalizada, e com crescente nível de dessacralização, perderam grande parte do status que possuíam na 
antiguidade. M.me Carlota representa no romance uma figura falsária que faz do sortilégio uma atividade mercantilizada. Aqui o ofício é marginal, tanto no sentido de perda de status em uma sociedade laica quanto de seu desvio dos âmbitos coletivos para o bem e o sucesso de uma comunidade.

\section{CONSIDERAÇÕES FINAIS}

Tendo por base as considerações de Cândido (1976) sobre a migração do universo externo para o interno na obra literária, a concepção de linguagem referida e dos teóricos sobre o universo laboral citados, chega-se às seguintes reflexões acerca do universo do trabalho como um dos elementos formalizadores das personagens. A ascendente industrialização no sul do país na década de setenta do século XX foi um chamariz para diversos trabalhadores, em especial os nordestinos, em busca de emprego no meio urbano, os quais estão representados, parcialmente, pelas figuras de Olímpico e Macabéa. O trabalho mecânico e alienador, aliado ao modelo fordista-taylorista, é desprezado, almejando-se o trabalho imaterial, na figura de Olímpico que deseja ser representante popular no legislativo. A Autora preferiu não vincular Olímpico à figura histórica dos operários metalúrgicos brasileiros daquele período que se aproximam dos ideais marxianos de politização e alteração social. A personagem é dotada de um comportamento avesso à associação coletiva, reforçando o seu desejo de se auto-beneficiar a partir da política. O trabalho coletivo não sociabiliza a personagem; apenas serve como etapa no seu intuito de se apossar da política, privatizando-a.

O ambiente de trabalho exerce papel socializador, haja vista as relações, em certa medida, positivas entre as personagens Macabéa, Raimundo e Glória. O ambiente da micro empresa, diferenciado das grandes plantas fabris, assemelha-se, pela proximidade entre proprietário e empregados, do cenário familiar em que relações pessoalizadas são hegemônicas. Porém, atitudes maternais e paternais daí emergem, esvaziando a possibilidade de conflitos e de reivindicações trabalhistas. Entretanto, de um modo diferente do apregoado pelos ideais marxianos, tem-se uma certa sociabilidade que aflora nesse ambiente. Embora haja certo intimismo nas relações, isso não oblitera totalmente a capacidade de Macabéa se ver como diferente dos demais. O episódio da curiosidade da personagem pela obra do 
escritor russo demonstra claramente certa politização de Macabéa ao se identificar com os "ofendidos e humilhados". O ambiente laboral, portanto, propicia a Macabéa, a construção de uma certa consciência de pertencimento a uma classe social, o questionamento do trabalho intelectual e sua subjetivação e a ponte entre universo laboral e a vida cotidiana fora do trabalho. Além disso, altera sua identidade anterior, ocorrendo uma hibridização em que se fundem sua constituição anterior e a atual: o advento do trabalho na função de datilógrafa, em meio urbano carioca, em uma micro empresa, modifica, em parte, a personagem.

O trabalho mecanicista também pode alienar o que é representado pela personagem Glória, ausente de questionamentos e reflexões tanto na vida fora do trabalho quanto neste. A personagem encontra no trabalho apenas uma extensão de sua vida familiar, econômica e cultural em que impera uma certa ordem que não deseja alterar. Trabalho e vida se interconectam pela ausência de sentido de mudança.

O ofício do escritor é representado em suas contradições, desafios e insuficiências à medida que se debruça sobre uma realidade que lhe resiste, que lhe é estranha, mas que sobre ela deve narrar algo. A escrita é mediada pelo contexto e pela classe social, sendo impactada por esses mirantes. O trabalho imaterial é árduo, penoso, recriando o real, mas padecendo, muitas vezes de pontes com esse mesmo real. Entretanto, o escritor, movido por certa teleologia, ou seja, tendo o objetivo de recriar o dado externo, constitui a sua individualidade nesse processo, pois emerge como sujeito criativo a partir do trabalho intelectual que é fruto da interação e embate com o outro.

Na figura do médico observa-se o trabalho como um produto mercantilizado e que não dignifica ou socializa, uma vez que distorcido pela estratificação social. A divisão social enfraquece o trabalho à medida que impede que seus frutos sejam generalizados, beneficiando a todos. Sucintamente, tem-se a abordagem do ofício das "Marias" caracterizado como um trabalho alienado, anônimo e genérico, o que exige pouca qualificação. Porém, a Autora as representa a partir do âmbito do trabalho, único contexto em que podem emergir como personagens, mas não como sujeitos com capacidade de problematizar esse ambiente. E por fim, o ofício da cartomante representado como um artifício de engodo e extorsão, esvaziado por um contexto moderno em que a ciência impera sobre o místico, desautorizando essa 
atividade cuja genealogia remonta à Grécia antiga, quando gozava de status e proeminência na sociedade.

Assim, vê-se que o universo do trabalho se encontra presente na obra e a narração sobre ele destaca uma série de contradições de classe, de saberes e de sentido. Clarice Lispector fez migrar o âmbito do trabalho para o interior do discurso ficcional e demonstra que aquele pode tornar ou não significativa a vida de certas personagens. O trabalho é representado a partir de várias facetas, propiciando a emergência do sujeito, a construção da individualidade, a problematização do pertencimento de classe, o planejamento a partir de uma teleologia e a sociabilidade, sobretudo, no ambiente das pequenas empresas. Por outro lado, surge o trabalho estranhado à medida em que aliena o sujeito tanto a partir do processo produtivo mecanicista em que o trabalhador se subordina ao ritmo da maquinaria quanto da divisão de classe social que afasta o trabalhador dos demais, impedindo que os frutos do trabalho beneficiem a todos. $O$ trabalho imaterial da arte se contrapõe ao da política visto que naquele a Autora concentra uma série de problematizações acerca das dificuldades e dos desafios de sua operacionalização e neste preferiu apontar somente a dimensão redutora em que ocorre a privatização do espaço público. Emerge daí uma concepção positiva sobre a centralidade do trabalho como elemento possível de propiciar a sociabilidade e a emancipação, dialogando, no campo literário, com os teóricos que destacam a centralidade do trabalho como constituinte do ser social. 


\section{REFERÊNCIAS}

ANTUNES, R. Os Sentidos do Trabalho: Ensaio sobre a Afirmação e Negação do Trabalho. 6 ed. São Paulo: Boitempo, 2002.

ANTUNES, R. Adeus ao Trabalho? Ensaio sobre as metamorfoses e a centralidade do mundo do trabalho.10. ed. São Paulo: Cortez; Campinas: Ed. da Universidade Estadual de Campinas, 2005.

ASSIS, M. Literatura Brasileira - Instinto de Nacionalidade. Crítica literária. Rio de Janeiro; São Paulo; Porto Alegre: Jackson, 1955.

BAUMAN, Z. Sociedade individualizada: vidas contadas e histórias vividas.Tradução José Gradel. Rio de Janeiro: Zahar, 2008.

BAKHTIN, B; VOLOCHINOV, V.N. Marxismo e Filosofia da linguagem: Problemas fundamentais do Método Sociológico na Ciência da Linguagem. Tradução Michel Lahud e Yara Frateschi Vieira. São Paulo: Hucitec, 1986.

BAKHTIN, B. Questões de literatura e estética: a teoria do romance. Tradução Michel Lahud e Yara Frateschi Vieira. São Paulo: Editora Hucitec, 1988.

CANDIDO, A. Crítica e Sociologia. In: Literatura e Sociedade. 5 ed. São

Paulo: Nacional, 1976.

ENGELS, F. O papel do trabalho na transformação do macaco em homem. 4. ed. Rio de Janeiro: Global, 1990.

LISPECTOR, C. A Hora da Estrela. 12 ed. Rio de Janeiro: Rocco, 1998.

LUKÁCS, G. The ontology of social being: Labour. Londres: Merlin Press, 1980.

MANNHEIN, K. Ideologia e utopia. Rio de Janeiro: Guanabara, 1986. 
MARX, K. A Maquinaria e a Indústria Moderna. In: O Capital: Crítica da

Economia Política. Tradução Reginaldo Santanna. 12 ed. Rio de Janeiro: Bertrand, 1986.

RÜDIGER, F. Martin Heidegger e a questão da técnica: prospectos acerca do futuro do homem. Porto Alegre: Sulina, 2006. 